Мухарем Баздуљ

mbazdulj@hotmail.com

https://doi.org/10.18485/ai_gozik.2019.ch8

821.163.41.09-32 Кундера М.

\title{
ВАРИЈАЦИЈА НА МОТИВ ПЛАТОНОВЕ ГОЗБЕ У СМИЈЕШНИМ ЉУБАВИМА МИЛАНА КУНДЕРЕ
}

У раду се анализира књига прича Милана Кундере Смијешне љубави, са посебним акцентом на приповијетку „Симпозијум“, а у контексту њене везе са Платоновим дијалогом Гозба. Анализа почиње контекстуализацијом те књиге унутар Кундериног опуса те мјеста потенциране приповијетке унутар књиге, а затим се указује на илустрације начина на који се у њој варирају мотиви из Гозбе. Такође, сумирају се одређени мотиви из Гозбе и покушава се показати како се теме из античког филозофског дијалога инкорпорирају у савремени књижевни текст, уз иронијски отклон.

Кључне ријечи: Милан Кундера, Платон, филозофија, књижевност, Смијешне льубави, Гозба.

Почетком осамдесетих година прошлог вијека Милан Кундера дао је велики интервју Кристијану Салмону за њујоршки часопис „Paris Review“. Два дијела овог разговора Кундера је објавио засебно у својој књизи есеја Умјетност романа. Насловио их је као Дијалог о умјетности романа односно Дијалог о умјетности композииије. У другом дијалогу, оном о умјетности композииије, дакле, Кундера и Салмон заједно закључују како постоје двије форме-архетипа у Кундериним романима: 
1) полифонијска композиција која сједиғује разнородне елементе у архитектуру засновану на броју седам; 2) водвилска композиција, хомогена, театрална композиција, која додирује невјероватно. Кундера ће на ово надодати: Увијек сағарим о некој великој неочекиваној невјерности. Међутим, тренутно нисам успио измакнути бигамији тих двају форми.

Важно је напоменути како је у вријеме овог разговора посљедње Кундерино дјело било Неподношљива лакоћа постојана. Дотадашњи његов опус лако је, значи, раздијелити по назначеним категоријама. Првој припадају Шала, Смијешне тьубави, Живот је другдје, Книга смијеха и заборава те Неподноштива такоћа постојаға; другој категорији припада Опроштајни валиер те приповјетка „Симпозијум“ ван контекста Смијешних тьубави. ${ }^{1}$

Прва (и једина) књига прича Милана Кундере зове се Смијешне љубави. Као романсијер, Кундера је познат и по истраживању могућности инкорпорирања филозофске мисли у књижевност (најчувенији примјер је концепт Ничеовог „вјечног враћања“ у Нейоgношљивој лакоћи йостиојаюа). Први примјер таквог поступка, међутим, налазимо управо у Смијешним љубавима, у начину на који се варирају мотиви из Платонове Гозбе у краткој причи прикладног наслова „Симпозијум“.

Књига Смијешне тьубави једина је збирка прича у Кундерином опусу. Није, међутим, ријеч о „класичној“ књизи прича: седам приповијетки („Нико се неће

1 Овдје постоји и индикативна 'бројчана' подударност. Не ради се само о водвиљима; оба дјела су - како сам Кундера каже - водвиљи у пет чинова. Ипак, за разлику од брижљиво насловљених дијелова романа који припадају првој категорији овдје су наслови понешто схематични. Код Опроштајног валиера ријеч је о данима (Први дан, Други дан ...), а код Сумпосиона дословце о чиновима (Први чин, Други чин ...). 
смијати“, „Златна јабука вјечне чежње“, „Лажни аутостоп“, Симпозијум“, „Нека стари мртви уступе мјесто младим мртвима“, „Доктор Хавел послије десет година“, „Едуард и Бог“) из збирке заједно на извјестан начин теже роману, и то оном типу романа какав ће Кундера касније исписати у Книзи смијеха и заборава, роману којег не повезује толико јединствена фабула, колико извјесно мотивско јединство. Централни мотив Смијешних льубви, заједнички свакој од седам прича, могао би се назвати донхуанским. Доказ за централну улогу поменутог мотива јест и чињеница да доктор Хавел, привилегирани протагонист Смијешних тубави, једини који се појављује у двије приче из књиге („Симпозијум“ и „Доктор Хавел послије десет година“), на једном мјесту, након што га назову Дон Хуаном, на лудичко-есејистички начин призива носталгију за временом достојним „правог“ Дон Хуана.

Важност мотива Дон Хуана у овој књизи примијећена је чак и у једном кратком референтном француском приручнику у теорији књижевности:

У Смешним тьубавима, Кундера приказује - на пример неколико варијанти пучких Дон Хуана, који делују у једном деградираном друштву - пародија једне рђаво распоређене демократије - користећи одговарајућа ситна лукавства са неједнаким успехом. Мали свет, мала средства, антијунаци којима ипак не недостаје патос насупрот њиховом бедном свету. (Сантер Саркани 2001: 64)

Вриједи макар као бизарност навести чињеницу да се главни међу Кундериним Дон Хуанима, па и онај чија је улога најважнија и унутар приче „Симпозијум“, презива Хавел, баш као и онај Кундерин колега-књижевник који ће касније да предводи транзицију у Чешкој и с којим ће се Кундера разићи на начин који је привукао велику пажњу: 
Зашто је Милан Кундера, чак и сада после победе демократије, на неки начин екскомунициран у Чешкој? Његова дела се ретко објављују, медији ћутке прелазе преко њих, свакоме је некако незгодно да говори о њему... Да би се оправдало такво поступање, ишчачкавају се старе приче о његовој тајној колаборацији са комунистичким режимом, о његовом прибегавању личним задовољствима и избегавању морално исправних конфликата $a$ ла Хавел, итд. Међутим, корени овог отпора су дубљи Кундера емитује поруку коју „нормализована“ демократска свест не може да поднесе. (...) Тоталитарно стање је исходиште низа феномена о којима сведоче многобројне хронике свакодневног живота на социјалистичком истоку: реакција на тоталитарну идеолошку доминацију није се испољавала само као цинично бекство у „добар живот“ у виду личних задовољстава већ и као изузетно цветање аутентичних пријатељстава, кућних посета, заједничких вечера, страсних интелектуалних разговора у затвореним друштвима - одлике које су обично фасцинирале посетиоце са Запада. Проблем је, наравно, у томе што се не може повући јасна линија која раздваја две стране: оне су глава и писмо истог новчића, због чега су се, доласком демократије, обе изгубиле. Кундери иде у прилог то што не скрива ту двосмисленост: дух „Средње Европе“, аутентично пријатељевање и интелектуална дружељубивост, опстали су само у Чешкој, Мађарској и Пољској, као облик отпора доминацији тоталитарне идеологије (Жижек 1996: 103).

Вратимо се сада ипак самој причи. Ево како она почиње:

Соба за дежурства (на неком, било којем одјелу било које болнице у било којем граду) окупила је на једноме мјесту пет особа и испреплела њихове ријечи и поступке у неважан, али зато весео догађај.

Ту су доктор Хавел и сестра Алжбе̌та (обоје су дежурни те ноћи), а назочни су још неки лијечници (нашли су 
се ту под неким једва спомена вриједним изговором, да би уз неколико донијетих боца вина остали сједити с дежурнима): ћелави примаријус с истог одјела и привлачна тридесетогодишња докторица с другог одјела, за коју је цијела болница знала да је примаријусова љубавница. (Примаријус је, наравно, ожењен и управо је био изговорио своју омиљену сентенцу, која треба да свједочи не само о његовој духовитости него и о његовим намјерама: - Драге колеге, највећа несрећа која вас може снаћи је сретан брак; остајете без и најмање наде у развод.)

Осим четверо именованих, ту је и пети, али он, заправо, и није ту, јер је као најмлађи послан по нову боцу. Даље, ту је прозор, важан због тога што је отворен и што кроз њега из сумрака у собу непрестано струје мириси и топлина љета, заједно с мјесечином. Ту је, напосљетку, и добро расположење које се изражава ведром брбљавошћу присутних, а посебно примаријуса, увијек склона да заљубљеним ушима ослушкује своје властите досјетке. (Кундера 2000: 50)

Замислимо ли читаоца коме је непознато властито Кундерино аутопоетичко ${ }^{2}$ признање о чињеници да га је на ову причу надахнула Платонова Гозба, поставља се питање може ли тај читалац до истог закључка и сам да дође. Прва асоцијација би на једном нивоу морала да буде јасна. Ради се, наравно, о наслову. Симпозијум је, етимолошки гледано, гозба. Наравно, у контексту медицине, па и науке генерално, значење термина „сим-

2 „Он почива на формалном архетипу посве различитом од мојих других романа. Он је апсолутно хомоген, без дигресија, састављен од само једне твари, испричан у истом темпу, веома је театралан, стилизиран, заснован на форми водвиља. У Смијешним тьубавима можете прочитати новелу Колоквиј. На чешком она се зове Симпозијум, пародијска алузија на Платонов Сумпосион. Дуге расправе о љубави. Дакле, овај Симпозијум је компониран посве као Опроштајни валцер: водвиљ у пет чинова“. (Кундера 1984: 42) 
позијум“ се одмакло од термина „гозба“, али овдје ипак имамо довољно индикација које указују у правцу платоновске гозбе.

Ипак, прије него укажемо на поређења која ту имају смисла, присјетимо се најприје шта је тачно Платонова Гозба. Овај дијалог, парафразирајмо његовог преводиоца на српски Милоша Н. Ђурића, добио је име по гозби коју је у своме дому приредио млади трагички песник Агатон кад је, у трагичком надметању, год 416. о Ленејама, први пут стекао побједу својом тетралогијом. Гозба представља врхунац умјетничког развитка Платонове личности, она је његово највеће умјетничко дјело, у коме се удруживањем дијалектике и митскога уобличавања откривају најдубља сазнања. Она је огледало Платонове многостране личности, јер се у њој неразлучно удружују дијалектичарска оштрина, природњачка обдаредност посматрања, бесједничка моћ, пјесничка машта, мистичарска снага визије. На неки начин, ова Ђурићева интерпретација Платоновог стила у Гозби блиска је генерално оном дискурсу који Кундера назива романсијерским, првенствено по протејској способности да удружи много тога међусобно различитог. Такође, могуће је повући различите паралеле између пет главних ликова Кундериног „Симпозијума“ и седам бесједника из Гозбе. Телеграфски кратак опис Гозбе из пера Здеслава Дуката: „разговор уз пиће с тематиком љубави односно еротологије“ (Дукат 1996: 3) потпуно адекватно описује и Кундерину приповијетку.

Приповијетка је, рекосмо, подијељена у пет чинова, а сваки чин опет у засебне насловљене одјељке. Један од одјељака првог чина зове се „Похвала платонској љубави“. У њему се развија идеја да сексуалност није мјерило љубави, односно платонској љубави се приписује њена 
накнадна конотација као кад бисмо о симпозијуму говорили једино у регистру конференције. Ипак, сама референца на Платона представља додатно потцртавање алузија на Гозбу. Један од често цитираних ставова из Гозбе у овом контексту је парадигматичан: „Да, одиста, богови највише цене ову врлину која се односи на љубав; али у још већој мери чуде се и диве се и награђају кад је љубимац одан љубавнику него ли кад је љубавник одан љубимцу“ (Платон 2003: 30).

Био би потребан дужи текст да се подробније анализирају све потенцијалне паралеле између Платонових и Кундериних ликова, али овдје има смисла барем овлашно нотирати паралелу између Алкибијада и Доктора Хавела. Алкибијада је Гери Алан Скот памтљиво успоредио са Дон Хуаном, а веза између Доктора Хавела и Дон Хуана је један од темеља цијеле Кундерине приповијетке коју анализирамо. Монолог доктора Хавела у том смислу је карактеристичан:

Ако треба да одлучим јесам ли Дон Јуан или Смрт, морам се, премда нерадо, приклонити примаријусовом мишљењу - рекао је Хавел и отпио дуг гутљај. - Дон Јуан. Та он је био освајач. Чак освајач с великим О. Велики Освајач. А молим вас, како да човјек буде освајач на територији гдје му се нико не супроставља, гдје је све могуће и све је допуштено? Ера Дон Јуана је прошла. Данашњи Дон Јуанов потомак више не осваја, он само скупља. Лик Великог Освајача замијенио је лик Великог Сакупљача, с тим што Сакупљач више уопће није Дон Јуан. Дон Јуан је био лик из трагедије, био је оптерећен кривицом. Весело је гријешио и ругао се Богу. Био је подругљивац и завршио је у паклу.

Дон Јуан је носио на плећима драматичан терет о коме Велики Сакупљач нема појма, јер је у његовом свијету сваки терет изгубио тежину. Камење је претворено у 
перје. У свијету Освајача, један једини поглед тежио је као десет година најмарљивије тјелесне љубави у свијету Сакупљача.

Дон Јуан је био господар, док је Сакупљач роб. Дон Јуан је дрско кршио конвенције и законе. Велики Сакупљач послушно и у зноју лица свога проводи у дјело конвенције и законе, јер је сакупљање постало синоним доброг понашања, претворило се у бонтон и готово обавезу. (...) Велики Сакупљач нема ништа заједничко ни с трагедијом ни с драмом. Еротика, која је била исходиште катастрофа, његовом је заслугом почела да личи на доручак, ручак, филателију, пинг-понг, да не кажем вожњу трамвајем или куповину. Он је увео еротику у колотечину свакодневице. Претворио ју је у кулисе и даске позорнице на којој би тек требало да се одигра права драма. (...) Драга докторице и драги примаријусе, супроставили сте једно другом Дон Јуана и Смрт. Пуким случајем, и сасвим несвјесно, открили сте тиме суштину ствари. Видите, Дон Јуан се борио с немогућим, и управо то је веома људски. У царству Великог Сакупљача, међутим, не постоји немогуће јер је то царство смрти. Велики Сакупљач је Смрт која је дошла по трагедију, по драму, по љубав. Смрт која је дошла по Дон Јуана. У пакленој ватри, у коју га је послао комтур, Дон Јуан је жив, али у свијету Великог Сакупљача у коме страсти и осјећаји лете кроз прозор као паперје, у том свијету он је заувијек мртав.

$\mathrm{He}$, не, драга госпођо Докторице - рекао је тужно Хавел - гдје сам ја, а гдје је Дон Јуан! Шта бих дао да угледам комтура и осјетим на души страшну тежину његовог проклетства, да осјетим у себи узвишеност трагедије. Не, докторице, ја сам у најбољем случају лик из комедије, па ни за то не могу вјероватно захвалити себи, већ управо Дон Јуану, јер само на историјској позадини његове трагичне радости можете како-тако сагледати сву комичну тугу моје заводничке егзистенције, која би без те позадине била сива, свакодневна, досадна. (Кундера 2000: $57-58)$ 
Сам Кундера је у цитираном аутопоетичком фрагменту открио важност овдје анализиране приче у контексту његовог цјелокупног опуса. Често је писано о мјесту Гозбе унутар Платоновог опуса. Гозба није тек један од неколико Платонових дијалога, што се довољно јасно види већ и по његовом наслову. Већина његових дијалога носи име неког софисте или име битног саговорника. Гозба се већ именом очигледно разликује, а разликује се и тиме што она представља и неку врсту бесједничког такмичења истакнутих људи. Имајући у виду да је за Кундеру умјетничка проза истраживање постојања уз помоћ неколико експерименталних ега, није чудно да је пронашао инспирацију у овом Платоновом тексту. Уосталом, већ дуго се овај текст сматра нарочито инспиративним из умјетничке перспективе, чак и у случајевима кад је надахнуће плод интерпретација које многи сматрају и промашеним:

Гозба је можда најизврсније од свих Платонових резултата као драмског умјетника; можда је баш из тог разлога, била најпогрешније схваћена у односу на било које друго Платоново дјело. Чак је и у Ксенофонтово време била очигледно погрешно интерпретирана, што се може препознати и према тону његове инфериорне имитације под истим именом. Ксенофонт је у писању био вођен обликом дијалога који је подразумјевао да то значи расправу о сексуалној страсти и стварање провалије против ње у његовој Гозби, која доживљава свој климакс похвале у задовољствима брачног живота. Наша властита и посљедња генерација је, са отровом романтизма у жилама, отишла даље и открила да дијалог антиципира 'пророштва' Вилијама Блејка налазећи кључ космоса у чињеници секса (Тејлор 73: 1926).

Наравно да би у неком дужем раду било могуће и да се детаљније анализира Платонов утицај на писање 
Милана Кундере. Амбиција овог рада је, међутим, много скромнија. На трагу ширег оквира „Гозба и књижевност“ он жели да укаже на један конкретан примјер кориштења мотива из Платонове Гозбе у савременој књижевности. Међу ширим проблемским комплексима које би ваљало подробније истражити јест начин на који Кундера у неким каснијим књигама на понешто сличан начин варира друге филозофске идеје унутар књижевноумјетничког текста. Најславнији примјер је несумњиво варијација на Ничеову доктрину „вјечног враћања истог" у роману Неподношљива такоћа постојаға. У том смислу би занимљиво било анализирати и које филозофи су генерално гледајући у смислу утицаја више надахњивали писце и пјеснике неголи будуће филозофе. Чини се да међу такве несумњиво спадају управо Платон и Ниче. Такође, интересантно је да су са развојем романа они аспекти Платонових дијалога који су раније били првенствено привлачни драмским писцима, почињу све фреквентније бивати инкорпорирани прије у романе неголи у драме. Но то засад ипак остају тек наговјештаји за нека будућа истраживања.

\section{Извори и литература}

Дукат, Здеслав. „Платонов Симпозиј“. Платон, Ерос и филиа. Загреб: Деметра, 1996.

Жижек, Славој. Метастазе уживаюа. Београд: ХХ век, 1996 (превела са енглеског Слободанка Глишић)

Кундера, Милан. Смијешне љуббави. Загреб: Меандар, 2000.

(превео са чешког Никола Кршић)

Кундера, Милан. Умјетност романа. Сарајево: Веселин

Маслеша, 1984. (превео са француског Миле Пешорда) Платон. Гозба. Београд: Дерета, 2003. (превео са старогрчког 
Милош Н. Ђурић)

Сантер-Саркани, Стефан. Теорија кюижевности. Београд: Плато, XX век, 2001. (превела са француског Јелена Новаковић)

Scott, Garry Allan. Plato's Socrates as Educator. New York: SUNY Press, 2000.

Taylor, E.A. Plato The Man And His Work. London: Methuen \& Co. Ltd, 1926.

Muharem Bazdulj

\section{VARIATIONS OF PLATO'S “SYMPOSIUM“ IN MILAN KUNDERA'S “LAUGHABLE LOVES“}

The focus of this paper is in the analysis of Milan Kundera's book of short stories "Laughable Loves" and especially one particular short story ("Symposium") and their connections with famous Plato's "Symposium". After putting this book in the wider context of Kundera's ouvre the paper illustrates the way how Kundera is using classical philosophical dialogue in modern literature. In addition, the importance of Plato's "Symposium" is commented from the various perspectives, with emphasis on its inspirational quality for different artists. 